Article

\title{
Enzymatic resolution of epichlorohydrin catalyzed by whole cells in an organic solvent/buffer biphasic system
}

\author{
ZOU Shuping, YAN Haiwei, HU Zhongce, ZHENG Yuguo* \\ Institute of Bioengineering, Zhejiang University of Technology, Hangzhou 310014, Zhejiang, China
}

\section{A R T I C L E I N F O}

Article history:

Received 24 February 2013

Accepted 15 March 2013

Published 20 July 2013

\section{Keywords:}

Epoxide hydrolase

Whole cell

Chiral epichlorohydrin

Bioresolution

Organic solvent/buffer biphasic system

\begin{abstract}
A B S T R A C T
The biocatalytic resolution of $(R, S)$-epichlorohydrin to $(R)$-epichlorohydrin by whole cells from a recombinant Escherichia coli BL21(ED3) expressing epoxide hydrolase activity in a series of organic solvent/buffer biphasic systems was studied. Isooctane was found to be the best organic solvent. The optimum volume ratio of the organic phase to the aqueous phase, reaction temperature, $\mathrm{pH}$, substrate concentration, cell concentration, and reaction time were $7: 3,30^{\circ} \mathrm{C}, 8.0,574 \mathrm{mmol} / \mathrm{L}$, $0.07 \mathrm{~g} / \mathrm{ml}$ wet cells, and $45 \mathrm{~min}$, respectively. Under the optimized conditions, a yield of $37.5 \%$ with $99.3 \%$ ee and an average productivity of $0.286 \mathrm{~mol} /(\mathrm{L} \cdot \mathrm{h})$ were obtained in a stirred reactor (1-L scale). Thus, the bioconversion was more efficient in the isooctane/buffer biphasic system than that in a monophasic aqueous system, where the substrate concentration and the average productivity of $(R)$-epichlorohydrin were improved by $55.2 \%$ and $98.6 \%$, respectively.
\end{abstract}

(C) 2013, Dalian Institute of Chemical Physics, Chinese Academy of Sciences. Published by Elsevier B.V. All rights reserved.

\section{Introduction}

Epichlorohydrin (ECH) is an important organic intermedium. As a promising enantiopure epoxide, $(R)$-ECH and $(S)$-ECH are important $\mathrm{C}_{3}$ chiral building blocks for applications in medical, pesticide, chemical, material, and many other industries $[1,2]$. For example, $(R)$-ECH serves as a key chiral intermediate for the synthesis of angina pectoris drugs, such as metoprolol and alprenolol $[3,4]$. (S)-ECH is one of the precursors of statins, which is the highest selling cholesterol-lowering drug with global sales of $\$ 20$ billion [5].

In recent years, because of maturing technology and the adaptation of a large-scale synthesis of ECH from glycerol, which is a by-product of biodiesel, the market price of ECH has fallen. Therefore, one of the most economic ways for preparing chiral ECH is the kinetic resolution of racemic ECH. A number of researchers have reported the biocatalytic resolution of ECH by epoxide hydrolase because of its high stereoselectivity and mild reaction conditions [6]. Choi et al. [7] reported the enantioselective hydrolysis of racemic ECH for the production of $(S)$-ECH using Aspergillus niger cells. (S)-ECH could be obtained from its racemate $(60 \mathrm{mmol} / \mathrm{L})$ with an optical purity of $100 \%$ enantiomeric excess (ee) in 20\% yield. Kim et al. [8] investigated enantioselective hydrolysis for preparing $(R)$-ECH with an enantiopurity of $100 \%$ ee and a yield of $26 \%$ from $50 \mathrm{mmol} / \mathrm{L}$ racemate mixture using Pichia pastoris recombinantly expressing the enantioselective epoxide hydrolase from Rhodotorula glutinis. Woo et al. [9] demonstrated the chiral resolution of racemic ECH to prepare $(S)$-ECH using the enantioselective epoxide hydrolase from Novosphingobium aromaticivorans with a $99.99 \%$ ee and yield of $20.7 \%$ (theoretical, $50 \%$ ) from a $500 \mathrm{mmol} / \mathrm{L}$ racemate mixture. However, because of the low substrate concentration and low yield, some improvements are still necessary prior to practical applications of

\footnotetext{
* Corresponding author. Tel/Fax: +86-571-88320630; E-mail: zhengyg@zjut.edu.cn This work was supported by the National Basic Research Program of China (973 Program, 2011CB710806), the National Natural Science Foundation of China (21176224), and the Specialized Research Fund for the Doctoral Program of Higher Education of China (New Teachers, 2012331712004). DOI: 10.1016/S1872-2067(12)60576-2 | http://www.sciencedirect.com/science/journal/18722067 | Chin. J. Catal., Vol. 34, No. 7, July 2013
} 
these techniques.

Escherichia coli strain expressing epoxide hydrolase from Agrobacterium radiobacter AD1 was constructed in our lab in a previous study [10]. The epoxide hydrolase was highly stereoselective and could prepare $(R)$-ECH from ECH. However, the epoxide would easily undergo spontaneous hydrolysis when the reaction was performed in an aqueous system, which leads to an inefficient reaction and the production of by-products, which were toxic to the biological catalyst [11]. An organic solvent/buffer biphasic system provides a very promising alternative to overcome this shortcoming [12-15]. In this study, E. coli cells recombinantly expressing an epoxide hydrolase were employed as whole cell catalysts for the enantioselective resolution of ECH to prepare $(R)$-ECH in an organic solvent/buffer biphasic system. The influence of the biphasic system on the reaction is systematically discussed herein.

\section{Experimental}

\subsection{The cultivation of whole cells and their preparation}

The recombinant E.coli expressing the epoxide hydrolase gene (GenBank: Y12804.1) from Agrobacterium radiobacter AD1 was reported previously and was preserved in our lab [10]. The cultivation of recombinant E. coli BL21 (DE3) was described previously [16]. The cells were harvested by centrifugation $\left(10000 \mathrm{r} / \mathrm{min} \times 10 \mathrm{~min}, 4^{\circ} \mathrm{C}\right)$, washed twice with physiological saline, stored at $-20^{\circ} \mathrm{C}$ until further use.

\subsection{Bio-resolution of ECH in a biphasic system}

Racemic ECH, $(S)$-ECH and $(R)$-ECH (99\%) were purchased from FuChen Chemical Co, Ltd. (Xi'an, China). All other chemicals were from commercial sources and of analytical or chromatographic grade. A suitable amount of wet cells, a certain volume of phosphate buffer $(0.2 \mathrm{~mol} / \mathrm{L}, \mathrm{pH} 8.0)$, and isooctane were added into a $50 \mathrm{ml}$ bottle with a stopper. Then a suitable amount of racemic ECH was added and stirred (400 r/min) for $15 \mathrm{~min}$. After sampling and centrifugation $(12000 \mathrm{r} / \mathrm{min} \times 2$ min), ethyl acetate was added for extracting ECH for further GC analysis.

Samples were analyzed using a GC-14A gas chromatograph (Shimadzu, Japan) equipped with an FID detector and a chiral chromatographic column BGB-175 (30 $\mathrm{m} \times 0.25 \mathrm{~mm} \times 0.25 \mathrm{~m}$ ). The temperatures of the injector and flame ionization detector were set to $220^{\circ} \mathrm{C}$. The column oven temperature was maintained at $90{ }^{\circ} \mathrm{C}$ for $7 \mathrm{~min}$. The carrier gas was $\mathrm{He}(1.6 \mathrm{ml} / \mathrm{min})$, the flow rate was $1.6 \mathrm{ml} / \mathrm{min}$, and the split ratio was $1: 40$. The retention times were $5.3 \mathrm{~min}$ for $(R)-\mathrm{ECH}$ and $5.6 \mathrm{~min}$ for $(S)$-ECH.

The molar yield $(Y)$, average productivity $\left(Y_{1}\right)$, and ee were calculated according to the residual $\mathrm{ECH}$. The molar yield was determined from $Y=c / c_{0} \times 100 \%$, where $c_{0}$ and $c$ denote the beginning and the ending molar concentration of ECH, respectively. Average productivity was calculated from $Y_{1}=c / t$, where $c$ and $t$ denote the molar concentration of $(R)$-ECH and the end of the reaction time, respectively. ee was calculated from ee =
$\left(c_{\mathrm{R}}-c_{\mathrm{S}}\right) /\left(c_{\mathrm{R}}+c_{\mathrm{S}}\right) \times 100 \%$, where $c_{\mathrm{R}}$ and $c_{\mathrm{S}}$ denote the molar concentration of $(R)$-ECH and $(S)$-ECH, respectively.

\section{Results and discussion}

\subsection{Selection of organic solvents}

Generally, organic solvents have toxic effects on biological cells and enzymes, which result in decreased biological activities. Six kinds of hydrophobic organic solvents (isobutanol, isopropanol, cyclohexane, isooctane, $n$-heptane, and $n$-hexane) were tested as the organic phase for the biphasic system, and their effects on the resolution of $(R, S)$-ECH to $(R)$-ECH catalyzed by whole cells from a recombinant $E$. coli system were studied.

The ability of a solvent to sufficiently dissolve the substrate is an important factor to be considered when selecting it [17]. The solubility of ECH in the six tested organic solvents was investigated in our study. The solubility values $\left(20^{\circ} \mathrm{C}\right)$ of $\mathrm{ECH}$ were 22.1, 18.5, and $19.0 \mathrm{~g} / 100 \mathrm{~g}$ solvent in isooctane, $n$-heptane, and $n$-hexane, respectively, and it was miscible with isobutanol, isopropanol, and cyclohexane. Thus, compared to its low solubility in an aqueous system (6.58), organic solvents are more efficient for dissolving ECH. The second criterion that must be considered when selecting an organic solvent is its biocompatibility. As shown in Fig. 1, various organic solvents had different effects on the yield and ee. Isobutanol and isopropanol were miscible with ECH, however, the ee of $(R)$-ECH was almost zero when either was used as the reaction medium. The reason may be due to the toxicity of these solvents on the epoxide hydrolase, which decreased the overall enzymatic catalytic activity. The molar yields were much lower for cyclohexane, $n$-heptane, and $n$-hexane although the ee values were higher. It is important to note that the molar yield and ee were both higher when using isooctane as the reaction medium, which indicated that isooctane was biocompatible with the epoxide hydrolase. Bottalla et al. [18] and Gong et al. [11] also found that isooctane was biocompatible with epoxide hydro-

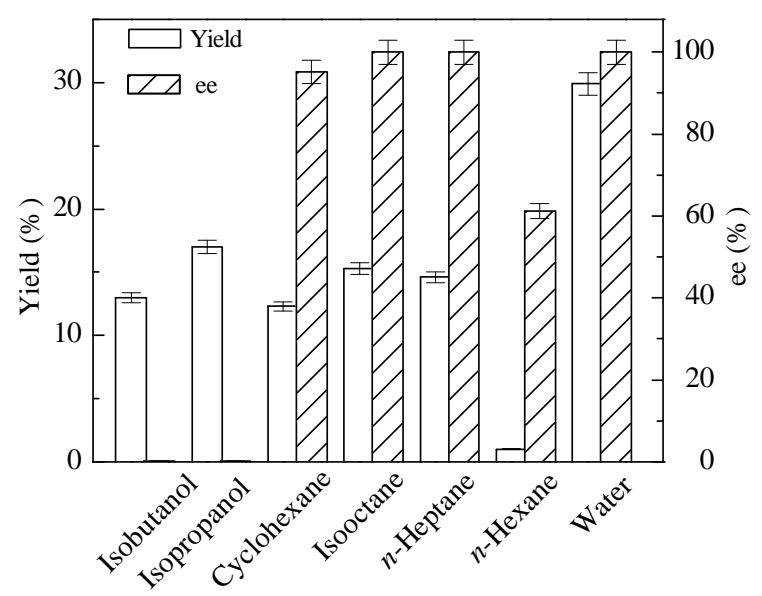

Fig. 1. Effects of various organic solvents on the yield and enantiomeric excess (ee) of the biocatalytic resolution of $(R, S)$-ECH for the production of $(R)$-ECH in the biphasic system using recombinant $E$. coil cells expressing epoxide hydrolase. Reaction conditions: $30 \mathrm{ml}$ organic solvent, $127.6 \mathrm{mmol} / \mathrm{L} \mathrm{ECH}, 0.01 \mathrm{~g} / \mathrm{ml}$ of $E$. coli cells, $30^{\circ} \mathrm{C}, 400 \mathrm{r} / \mathrm{min}$. 


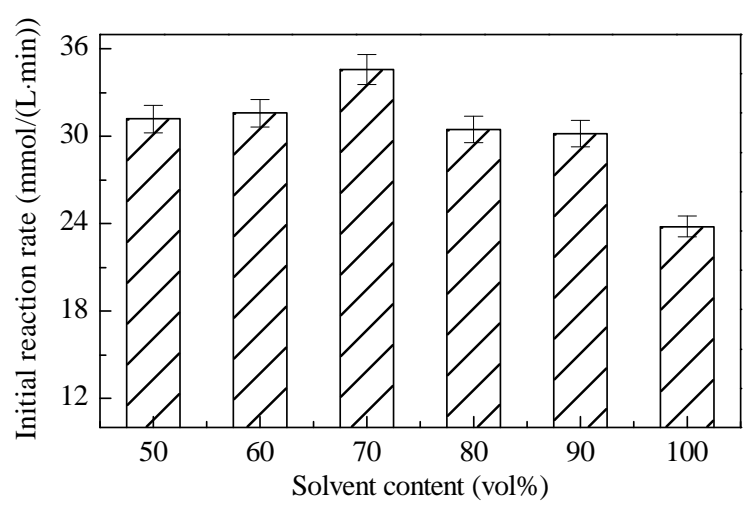

Fig. 2. Effect of isooctane volume ratio on the initial reaction rate of the biocatalytic resolution of $(R, S)$-ECH. Reaction conditions: $30 \mathrm{ml}$ biphasic solution containing different volumes of isooctane and buffer $(0.2$ $\mathrm{mol} / \mathrm{L}, \mathrm{pH} 8.0$ ), $127.6 \mathrm{mmol} / \mathrm{L} \mathrm{ECH}, 0.01 \mathrm{~g} / \mathrm{ml}$ of E. coli cells, $30^{\circ} \mathrm{C}, 400$ $\mathrm{r} / \mathrm{min}$.

lases expressed by Bacillus megaterium ECU1001 and Aspergillus niger. Thus, isooctane was selected as the organic solvent for the biphasic system.

\subsection{Effect of volume ratio of the organic and aqueous phase}

The volume ratio of the organic and aqueous phase was defined as $V_{\mathrm{o}} / V_{\mathrm{a}}(V / V)$, where $V_{\mathrm{o}}$ is the volume of organic solvent and $V_{\mathrm{a}}$ is the volume of the aqueous phase. A change in $V_{\mathrm{o}} / V_{\mathrm{a}}$ is thought to affect the interfacial area of the biphasic system, and in turn, the biological catalytic rate [19]. In our study, the effect of $V_{\mathrm{o}} / V_{\mathrm{a}}$ on the reaction was explored with the initial reaction rate being the study target. As shown in Fig. 2, the initial reaction rate increased as the volume of isooctane increased. In addition, there was a sharp decline in reaction rate when the volume ratio was over $70 \%$. Generally, once in contact with the organic solvent, enzymes and living cells always experience some degree of denaturation and deactivation. In the biphasic system, most of the substrate ECH existed in the organic phase, therefore, its low concentration in the aqueous phase led to a decrease in toxic and inhibition effects on the cells. However, an excess of organic solvent will disrupt the water film on the enzyme surface and the enzyme activity will be reduced or even lost [20]. According to the change of the initial reaction rate, $7: 3(V / V)$ was determined to be the optimum $V_{\mathrm{o}} / V_{\mathrm{a}}$ in our study.

The partition coefficients of ECH and the byproduct 3-chloro-1,2-propanediol (MCH) in the isooctane/buffer biphasic system are shown in Table 1 . In the range of tested $V_{\mathrm{o}} / V_{\mathrm{a}}$, the partition coefficients of ECH improved rapidly with an in-

Table 1

Partition coefficients $(K)$ of $(R, S)$-ECH and $(R, S)$-MCH in the two-phase system.

\begin{tabular}{lcc}
\hline$V_{\mathrm{o}} / V_{\mathrm{a}}$ & $K(\mathrm{ECH})$ & $K(\mathrm{MCH})$ \\
\hline $1: 9$ & 1.152 & 0.001 \\
$3: 7$ & 1.434 & 0.001 \\
$5: 5$ & 1.774 & 0.001 \\
$7: 3$ & 1.824 & 0.001 \\
$9: 1$ & 1.987 & 0.001 \\
\hline
\end{tabular}

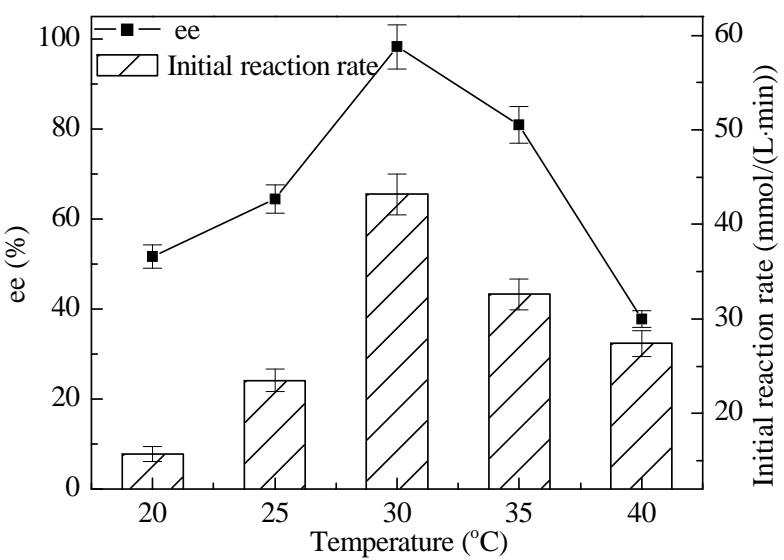

Fig. 3. Effect of temperature on the biocatalytic resolution of $(R, S)$-ECH. Reaction conditions: $21 \mathrm{ml}$ isooctane, $9 \mathrm{ml}$ buffer $(0.2 \mathrm{~mol} / \mathrm{L}, \mathrm{pH} 8.0)$, $127.6 \mathrm{mmol} / \mathrm{L} \mathrm{ECH}, 0.01 \mathrm{~g} / \mathrm{ml}$ of $E$. coli cells, $400 \mathrm{r} / \mathrm{min}$.

crease of isooctane volume while those of $\mathrm{MCH}$ were almost zero. This indicates that the organic solvent not only provided the interface of the biphasic system but was also used as the solvent to extract the product $(R)$-ECH effectively while leaving $\mathrm{MCH}$ in the aqueous phase. Thus, the use of an isooctane/buffer biphasic system could simplify the separation and purification of the product $(R)$-ECH.

\subsection{Effect of resolution temperature}

Reaction temperature is a key parameter in bioprocesses. It can significantly influence the activity, enantioselectivity, and stability of a biocatalyst as well as the reaction equilibrium [21]. Changes in the catalytic activity of the whole cells were studied from 20 to $40{ }^{\circ} \mathrm{C}$. As shown in Fig. 3, when the temperature was gradually increased from 20 to $30^{\circ} \mathrm{C}$, the initial reaction rate and ee significantly increased, and both reached a maximum at $30^{\circ} \mathrm{C}$. With further increasing in temperature, the initial reaction rate and ee began to decrease rapidly. The increase of temperature facilitates the binding of ECH by the enzyme while the collision probability between the enzyme and substrate will be increased. Both effects will result in an increase of reaction rate. Too high temperature causes damage to the spatial structure of the enzyme and decreases the activity of the cells, thus leading to decreases of ee and reaction rate. Therefore, $30{ }^{\circ} \mathrm{C}$ was determined to be the optimum reaction temperature, which was in accordance with that of epoxide hydrolase found by Woo et al. [9] and Lee et al. [22].

$\mathrm{ECH}$ in the aqueous phase is unstable and prone to spontaneous hydrolys resulting in a low yield of $(R)$-ECH [23]. The spontaneous hydrolysis rates of ECH in an aqueous phase system and a biphasic system were compared. As shown in Fig. 4, the spontaneous hydrolysis rate of $\mathrm{ECH}$ was $7.1 \%$ at $30{ }^{\circ} \mathrm{C}$ in the aqueous phase system and $4.9 \%$ in the biphasic system. As the temperature increased, the differences of the spontaneous hydrolysis rate between the two systems became more obvious. For example, the hydrolysis rate was $10.1 \%$ in the aqueous phase system while it was $7.2 \%$ in the biphasic system at $40{ }^{\circ} \mathrm{C}$. The spontaneous hydrolysis rate in the isooctane/buffer bipha- 


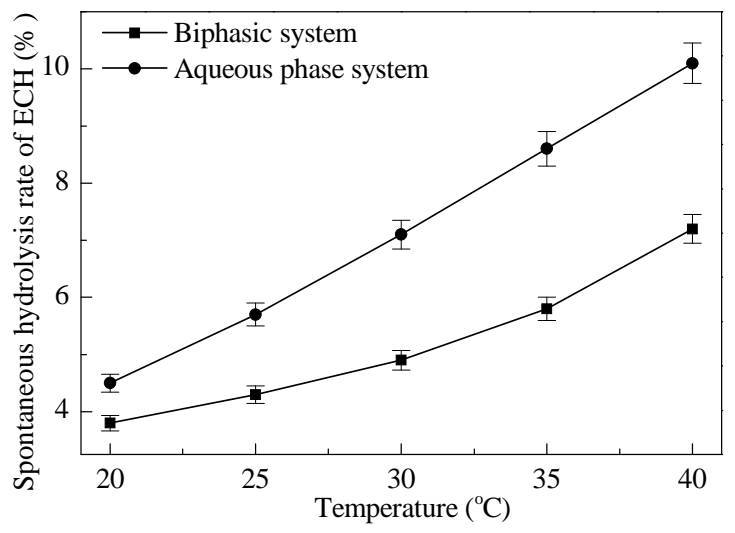

Fig. 4. Spontaneous hydrolysis rate of ECH in two different systems. Aqueous phase system: $30 \mathrm{ml}$ buffer $(0.2 \mathrm{~mol} / \mathrm{L}, \mathrm{pH} 8.0), 255.1 \mathrm{mmol} / \mathrm{L}$ $\mathrm{ECH}, 60 \mathrm{~min}, 400 \mathrm{r} / \mathrm{min}$. Biphasic system: $21 \mathrm{ml}$ isooctane, $9 \mathrm{ml}$ buffer (0.2 mol/L, pH 8.0), $255.1 \mathrm{mmol} / \mathrm{L} \mathrm{ECH,} 60 \mathrm{~min}, 400 \mathrm{r} / \mathrm{min}$.

sic system was obviously lower than in the aqueous phase system, which indicates that the biphasic system could inhibit the spontaneous hydrolysis of the substrate and improve the yield of the chiral product.

\subsection{Effect of buffer $p H$}

It is well known that a catalytic reaction usually occurs in the aqueous phase, which is also called the catalyst surplus phase. Variations in $\mathrm{pH}$ can alter the ionic state of the reaction substrates and enzymes as well as the enzymatic activity [24]. The effect of the $\mathrm{pH}$ of the aqueous buffer on the catalytic reaction rate was investigated at $\mathrm{pH}=7.0-9.0$ in the biphasic system.

As shown in Fig. 5, the initial reaction rate and ee increased gradually with $\mathrm{pH}$ reaching the maximum at $\mathrm{pH} 8.0$, and then decreased dramatically. This indicates that the cells had a maximum catalytic activity at $\mathrm{pH} 8.0$, in accordance with that of epoxide hydrolase previously reported $[8,25,26]$. Accordingly, pH 8.0 was determined to be optimum for further experiments.

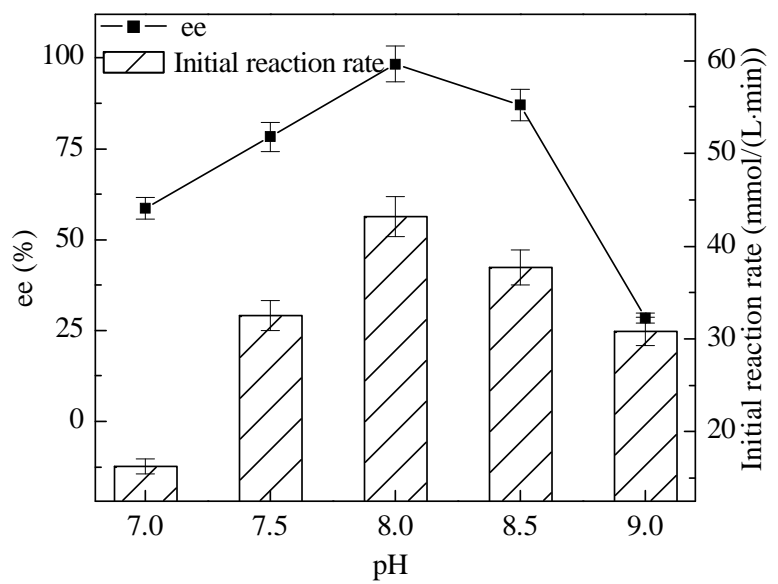

Fig. 5. Effect of $\mathrm{pH}$ on the biocatalytic resolution of ECH. Reaction conditions: $21 \mathrm{ml}$ isooctane, $9 \mathrm{ml}$ buffer $(0.2 \mathrm{~mol} / \mathrm{L}, \mathrm{pH} 8.0), 127.6 \mathrm{mmol} / \mathrm{L}$ $\mathrm{ECH}, 0.01 \mathrm{~g} / \mathrm{ml}$ of $E$. coli cells, $30^{\circ} \mathrm{C}, 400 \mathrm{r} / \mathrm{min}$.

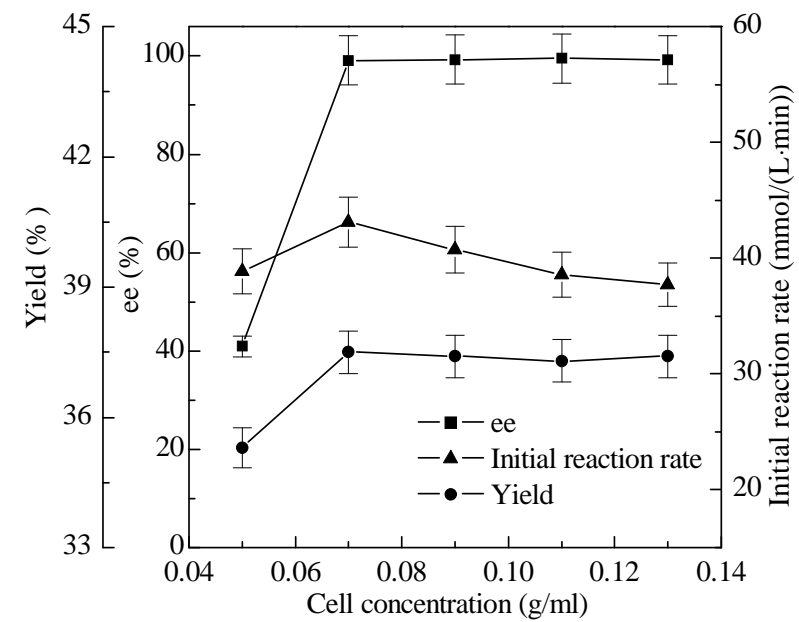

Fig. 6. Effect of cell concentration on the biocatalytic resolution of $(R, S)$-ECH. Reaction conditions: $21 \mathrm{ml}$ isooctane, $9 \mathrm{ml}$ buffer $(0.2 \mathrm{~mol} / \mathrm{L}$, $\mathrm{pH}$ 8.0), $574 \mathrm{mmol} / \mathrm{L} \mathrm{ECH}, 30^{\circ} \mathrm{C}, 400 \mathrm{r} / \mathrm{min}$.

\subsection{Effect of cell concentration}

Cell concentration is directly related to enzyme quantity and catalytic efficiency. Based on the same substrate concentration, if the higher the cell concentration, the faster the reaction rate. However, excessive biomass affects the mass transfer [27]. In our study, the cell concentration was altered while keeping the substrate concentration constant. Figure 6 shows that the ee, yield, and initial reaction rate all increased with increasing cell concentration with the maximum at $0.07 \mathrm{~g} / \mathrm{ml}$ cells. At higher cell concentrations, the initial reaction rate started to decrease although the yield and ee were not significantly affected. These results indicated an overdose of catalyst. Taking into account the cost and efficiency of the process, a cell concentration of $0.07 \mathrm{~g} / \mathrm{ml}$ was determined to be optimum for further studies.

\subsection{Effect of substrate concentration}

The substrate concentration is an important factor in kinetic resolution because a high concentration is toxic to cells and enzymes while a low concentration leads to a low reaction rate [28]. In the isooctane/buffer biphasic system, the effect of substrate concentration on the reaction was investigated with ee values as the target. As shown in Fig. 7, the biocatalytic resolution of $(R, S)$-ECH to $(R)$-ECH by whole cells was achieved with ee values of more than $99 \%$ when the substrate concentration was increased from 382.7 to $574 \mathrm{mmol} / \mathrm{L}$. When the substrate concentration was further increased, the ee values decreased to $46.2 \%$ at $637.8 \mathrm{mmol} / \mathrm{L}$ and $18.9 \%$ at $765.4 \mathrm{mmol} / \mathrm{L}$. These results might be explained by the fact that the substrate ECH is a non-natural substrate with poor biocompatibility, which is toxic to the cells at higher concentrations and influences the catalytic activity and enantioselectivity of the biocatalyst. Thus, the optimum concentration of ECH was determined to be 574 $\mathrm{mmol} / \mathrm{L}$.

\subsection{Bio-resolution of ECH in a mechanically stirred reactor}




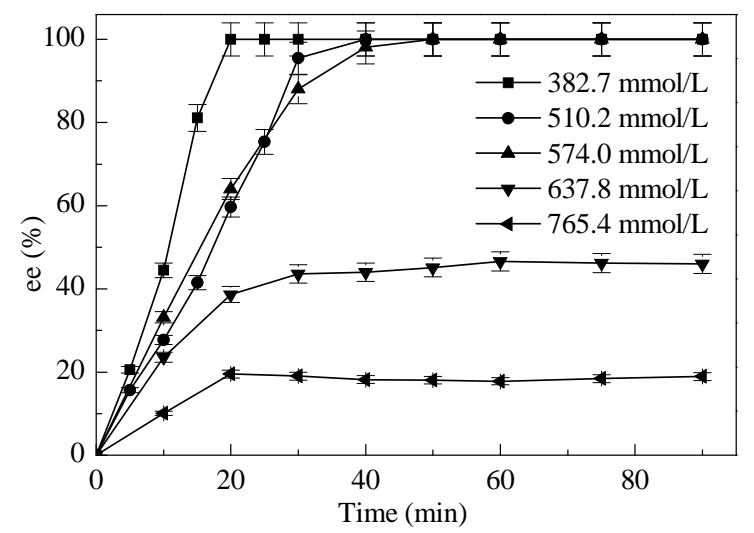

Fig. 7. Effect of substrate concentration on the biocatalytic resolution of $(R, S)$-ECH. Reaction conditions: $21 \mathrm{ml}$ isooctane, $9 \mathrm{ml}$ buffer $(0.2 \mathrm{~mol} / \mathrm{L}, \mathrm{pH} 8.0), 0.07 \mathrm{~g} / \mathrm{ml}$ of $E$. coli cells, $30{ }^{\circ} \mathrm{C}, 90 \mathrm{~min}, 400$ $\mathrm{r} / \mathrm{min}$.

According to the optimized conditions, $1 \mathrm{~L}$ of reaction liquid (isooctane/phosphate buffer ( $\mathrm{pH} 8.0$ ) volume ratio $=7 / 3$ ) containing $0.07 \mathrm{~g} / \mathrm{ml}$ wet cells and $574 \mathrm{mmol} / \mathrm{L}$ racemic ECH was added into a $2 \mathrm{~L}$ mechanically stirred reactor and subjected to continuous sampling and testing at $30^{\circ} \mathrm{C}$. As shown in Fig. 8, the cells showed a high stereoselectivity for ECH. The hydrolysis conversion rate of $(S)$-ECH into $\mathrm{MCH}$ was significantly faster than that of $(R)$-ECH. After terminating the reaction at $45 \mathrm{~min}$, the concentration of $(R)$-ECH was $215 \mathrm{mmol} / \mathrm{L}$, the molar yield was $37.5 \%$, the ee was $99.3 \%$, and the average productivity was $0.286 \mathrm{~mol} /(\mathrm{L} \cdot \mathrm{h})$. Compared with the aqueous monophonic system, the substrate concentration of ECH in the isooctane/buffer biphasic system was increased from 369.9 to 574 $\mathrm{mmol} / \mathrm{L}$, an improvement of $55.2 \%$, as well as the average productivity of $(R)$-ECH increased from 0.144 to 0.286 $\mathrm{mol} /(\mathrm{L} \cdot \mathrm{h})$, an improvement of $98.6 \%$.

Table 2 summarizes the biological methods for the bio-resolution of ECH published in the last several years. As shown in Table 2, the reported biological separation reactions are all in an aqueous monophonic system or an organic phase, and generally, the substrate concentration and productivity are not high. Woo et al. [9] reported the bio-resolution of ECH using epoxide hydrolase from recombinant $N$. aromaticivorans in an aqueous monophonic system at a high substrate concentration, $500 \mathrm{mmol} / \mathrm{L}$, but the yield of (S)-ECH was only $10.7 \%$. Lee et al. [22] carried out bio-resolution of ECH using an epoxide hydrolase from R. glutinis in an aqueous monophonic system with a

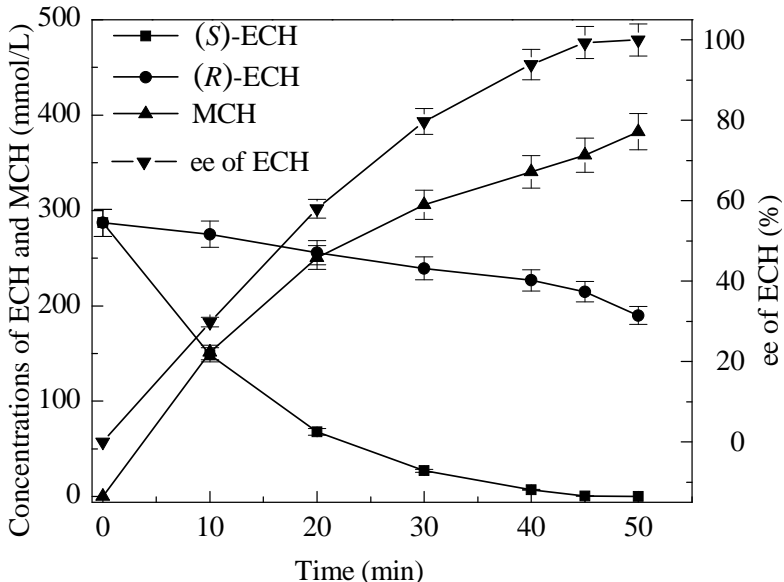

Fig. 8. Time course of biocatalytic resolution of $(R, S)$-ECH in the two phase system in a mechanically stirred reactor. Reaction conditions: 0.7 L isooctane, $0.3 \mathrm{~L}$ buffer $(0.2 \mathrm{~mol} / \mathrm{L}, \mathrm{pH} 8.0), 574 \mathrm{mmol} / \mathrm{L} \mathrm{ECH}, 0.07$ $\mathrm{g} / \mathrm{ml}$ of $E$. coli cells, $30^{\circ} \mathrm{C}, 50 \mathrm{~min}, 400 \mathrm{r} / \mathrm{min}$.

relatively high yield of (S)-ECH of $28.5 \%$, but the substrate concentration was only $20 \mathrm{mmol} / \mathrm{L}$. Therefore, compared with the existing reports, this study suggests that a biphasic whole-cell catalysis system could improve the concentration of substrate and yield of chiral ECH.

\section{Conclusions}

The biocatalytic resolution of $(R, S)$-ECH to $(R)$-ECH by whole cells of a recombinant Escherichia coli expressing epoxide hydrolase in organic solvent/buffer biphasic systems was studied. In an isooctane/buffer biphasic system, the enzymes from the whole cells could catalyze the bio-resolution of $(R, S)$-ECH to $(R)$-ECH with high efficiency and stereoselectivity. Isooctane can effectively improve the substrate concentration in the reaction system because the substrate ECH is soluble in it and this helps to suppress the non-enzymatic hydrolysis of the substrate. Under the optimized conditions in a stirred reactor (1-L scale), the substrate concentration was $574 \mathrm{mmol} / \mathrm{L}$ with a yield of $37.5 \%$, a product ee of $99.3 \%$, and an average productivity of $0.286 \mathrm{~mol} /(\mathrm{L} \cdot \mathrm{h})$. Compared with other published processes, the substrate concentration and the yield are improved in our method. However, as organic solvents are usually toxic to biological catalysts and are harmful to the environment, future studies will include efforts at recycling the organic solvent, as well as developing a continuous biphasic reaction system in

Table 2

The comparison of kinetic resolution of known epoxide hydrolases toward racemic ECH.

\begin{tabular}{|c|c|c|c|c|c|}
\hline Enzyme source & Reaction system & ECH concentration $(\mathrm{mmol} / \mathrm{L})$ & ee (\%)/Isomer & Yield (\%) & Reference \\
\hline Duck liver & aqueous & n.i. & $86.1 /(S)$ & n.i. & {$[26]$} \\
\hline Immobilized A. niger & aqueous & n.i. & $99 /(S)$ & 26 & [29] \\
\hline R. glutinis & aqueous & 50 & $100 /(R)$ & 26 & [8] \\
\hline Recombinant E. coli & aqueous & 127.6 & $99 /(R)$ & 18 & [16] \\
\hline N. aromaticivorans & aqueous & 500 & $99.9 /(S)$ & 10.7 & [9] \\
\hline R.glutinis & organic & 20 & $99 /(R)$ & 28.5 & {$[22]$} \\
\hline A. niger Spps & organic & 60 & $100 /(S)$ & 20 & [7] \\
\hline A. niger ZJB-09173 & organic & 153.6 & $98 /(S)$ & 18.5 & [30] \\
\hline Recombinant E. coli & biphasic & 574 & $99.3 /(R)$ & 37.5 & this study \\
\hline
\end{tabular}

n.i. No information. 


\title{
Graphical Abstract
}

Chin. J. Catal., 2013, 34: 1339-1347 doi: 10.1016/S1872-2067(12)60576-2

Enzymatic resolution of epichlorohydrin catalyzed by whole cells in an organic solvent/buffer biphasic system

ZOU Shuping, YAN Haiwei, HU Zhongce, ZHENG Yuguo*

Zhejiang University of Technology

An isooctane/buffer biphasic system is useful for dissolving the substrate epichlorohydrin (ECH) and suppressing its non-enzymatic hydrolysis. This biphasic system could prove useful for improving the concentration of substrate and yield of $(R)$-ECH.

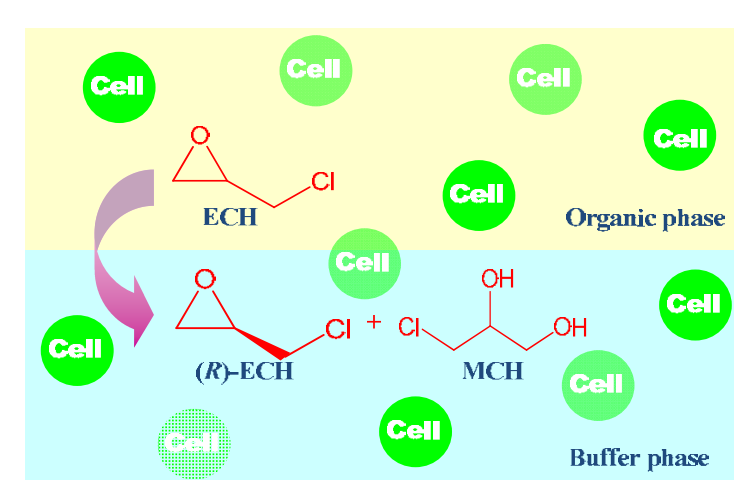

order to improve the efficiency of solvent usage and reduce the amounts of organic solvents employed.

\section{References}

[1] Wu J Y, Liu C, Jiang Y C, Hu M C, Li S N, Zhai Q G. Catal Commun, 2010, 11: 727

[2] Ling X Q, Lu D Q, Wang J, Tu Q B, Ren W, Ouyang P. Afr J Biotechnol, 2009, 8: 5534

[3] Jung S H, Linh T, Lim H-K, Kim H-J, Kim K-H, Kang J S. Arch Pharm Res, 2000, 23: 226

[4] Zhang J Y, Liu H M, Wang X J, Wang P, Zheng J X. Chirality, 2009, 21: 745

[5] Sun F L, Xu G, Wu J P, Yang L R. Tetrahedron: Asymmetry, 2007, 18: 2454

[6] Wohlgemuth R. Curr Opin Microbiol, 2010, 13: 283

[7] Choi W J, Lee E Y, Yoon S J, Yang S T, Chop C Y. J Biosci Bioeng, 1999, 88: 339

[8] Kim H S, Lee J-H, Park S, Lee E Y. Biotechnol Bioproc Eng, 2004, 9: 62

[9] Woo J H, Hwang Y O, Kang J H, Lee H S, Kim S J, Kang S G. J Biosci Bioeng, 2010, 110: 295.

[10] Jin H X, Liu Z Q, Hu Z C, Zheng Y G. Biochem Eng J, 2013, 74: 1

[11] Chen W J, Lou W Y, Wang X T, Zong M H. Chin J Catal (陈文静, 娄文 勇, 王晓婷, 宗敏华. 催化学报), 2011, 32: 1557

[12] Gong P-F, Xu J-H. Enzyme Microb Technol, 2005, 36: 252

[13] Ma X T, Xin B P, Wu Y, Chen G, Wu F, Chen S. Chin J Inorg Chem (马 兴泰, 辛宝平, 吴芗, 陈岗, 吴锋, 陈实. 无机化学学报), 2011, 27: 687
[14] Fuhshuku K I, Asano Y. J Biotechnol, 2011, 153: 153

[15] Wu X D, Han X X, Zhou L X, Li A. Asian J Chem, 2012, 24: 5151

[16] Liu Z Q Zhang L P, Cheng F, Ruan L T, Hu Z C, Zheng Y G, Shen Y C. Catal Commun, 2011, 16: 133

[17] Leon R, Fernandes P, Pinheiro H M, Cabral J M S. Enzyme Microb Technol, 1998, 23: 483

[18] Bottalla A L, Ibrahim-Ouali M, Santelli M, Furstoss R, Archelas A. Adv Synth Catal, 2007, 349: 1102

[19] Cruz A, Fernandes P, Cabral J M S, Pinheiro H M. Enzyme Microb Technol, 2004, 34: 342

[20] He J Y, Sun Z H, Zheng P, Hang L. J Chem Eng Chin Univ (何军邀, 孙 志浩, 郑璞, 韩丽. 高校化学工程学报), 2007, 21: 310

[21] Fu C C, Hung T C, Chen J Y, Su C H, Wu W T. Biosci Technol, 2010, 101: 8750

[22] Lee E Y.J Ind Eng Chem, 2007, 13: 159

[23] Choi W J, Huh E C, Park H J, Lee E Y, Choi C Y. Biotechnol Tech, 1998, 2: 225

[24] Zhang Z J, Pan J, Liu J F, Xu J H, He Y C, Liu Y Y.J Biotechnol, 2011, 152: 24

[25] Pawlik K, Kotowska M, Chater K F, Kuczek K, Takano E. Arch Microbiol, 2007, 187: 87

[26] You Z Y, Liu Z Q Zheng Y G. Appl Microbiol Biotechnol, 2013, 97: 9

[27] He Q, Xu Y, Teng Y, Wang D. Chin J Catal (贺芹, 徐岩, 滕云, 王栋. 催化学报), 2008, 29: 41

[28] Li A T, Zhang J D, Yu H L, Pan J, Xu J H. Process Biochem, 2011, 46: 689

[29] Yildirim D, Tükel S S, Alptekin Ö, Alagöz D. J Mol Catal B, 2013, 88: 84

[30] Jin H X, Hu Z C, Zheng Y G. J Biosci, 2012, 37: 695

\section{有机溶剂/缓冲液两相体系中全细胞催化拆分环氧氯丙烷}

\author{
邹树平，颜海蔚，胡忠策，郑裕国* \\ 浙江工业大学生物工程研究所, 浙江杭州310014
}

\begin{abstract}
摘要: 研究了有机溶剂/缓冲液两相体系中重组大肠杆菌E.coli BL21 (DE3)全细胞水解动力学拆分外消旋环氧氯丙烷制备 $(R)$-环 氧氯丙烷的过程. 结果表明, 最适反应条件为: 最适有机溶剂异辛烷与缓冲液的体积比 7:3, 最适缓冲液 $\mathrm{pH} 8.0$, 底物浓度 574 $\mathrm{mmol} / \mathrm{L}$, 全细胞加入量 $0.07 \mathrm{~g}$ 湿菌体 $/ \mathrm{ml}$ 溶液, 温度 $30{ }^{\circ} \mathrm{C}$. 在此条件下于 $1 \mathrm{~L}$ 应器中反应 $45 \mathrm{~min},(R)$-环氧氯丙烷的摩尔产率、光学 纯度和时空产率分别达到 $37.5 \%, 99.3 \% \mathrm{ee}$ 和 $0.286 \mathrm{~mol} /(\mathrm{L} \cdot \mathrm{h})$. 与单一水相体系相比, 异辛烷/缓冲液两相体系中底物浓度和 $(R)$-环 氧氯丙烷时空产率分别提高了55.2\%和 $98.6 \%$.
\end{abstract}


关键词：环氧化物水解酶；全细胞；手性环氧氯丙烷；生物拆分；有机溶剂/缓冲液双相体系

收稿日期: 2013-02-24. 接受日期: 2013-03-15. 出版日期: 2013-07-20.

*通讯联系人. 电话: (0571)88320630; 传真: (0571)88320630; 电子信箱: zhengyg@zjut.edu.cn

基金来源: 国家重点基础研究发展计划(973计划, 2011CB710806); 国家自然科学基金(21176224); 高等学校博士学科点专项科研 基金(新教师类, 2012331712004).

本文的英文电子版由Elsevier出版社在ScienceDirect上出版(http://www.sciencedirect.com/science/journal/18722067).

\section{1. 前言}

环氧氯丙烷 $(\mathrm{ECH})$ 是一种重要的有机合成中间体, 其单一对映异构体 $(R)-\mathrm{ECH}$ 和 $(S)-\mathrm{ECH}$ 均是非常重要的 三碳手性合成砌块, 在医药、农药、化工和材料等领域 有非常广泛的应用 ${ }^{[1,2]}$. 例如, $(R)-\mathrm{ECH}$ 是合成治疗心绞 痛类药物美托洛尔和阿普洛尔等的关键手性中间体 ${ }^{[3,4]}$, (S)-ECH是目前临床上用量最大、全球销售额达 200 亿美 元的他汀类降血脂药物的起始原料之一 ${ }^{[5]}$.

近年来, 随着生物柴油副产物甘油合成ECH技术的 日益成熟及规模化应用, ECH市场价格持续走低. 因此, 以外消旋 $\mathrm{ECH}$ 为原料制备手性ECH已成为非常经济有 效的途径之一. 同时, 由于生物拆分法具有立体选择性 高和反应条件温和等优点 ${ }^{[6]}$, 因此不少研究者报道了利 用生物催化拆分法制备光学纯的ECH. Choi等 ${ }^{[7]}$ 采用来 自黑曲霉(Aspergillus niger)的环氧化物水解酶催化拆分 $\mathrm{ECH}$ 制备(S)-ECH, 底物浓度 $60 \mathrm{mmol} / \mathrm{L}$, 产率为 $20 \%$, 对 映体过量值 (ee) 为 $100 \%$. Kim 等 ${ }^{[8]}$ 利用胶红酵母 (Rhodotorula glutinis)的重组环氧化物水解酶催化拆分 $\mathrm{ECH}$ 制备 $(R)-\mathrm{ECH}$, 底物浓度 $50 \mathrm{mmol} / \mathrm{L},(R)-\mathrm{ECH}$ 产率为 $26 \%$, ee值为 $100 \%$. Woo 等 ${ }^{[9]}$ 利用来自海洋新鞘氨醇杆 菌(Novosphingobium aromaticivorans)的环氧化物水解酶 催化拆分 $\mathrm{ECH}$ 制备(S)-ECH, 底物浓度 $500 \mathrm{mmol} / \mathrm{L}$, (S)-ECH产率为 $20.7 \%$, ee值大于 $99 \%$. 由于底物浓度偏 低, 且产率普遍不高, 离实际应用尚有距离.

本实验室前期构建了一株表达放射形农杆菌 (Agrobacterium radiobacter) AD1环氧化物水解酶基因 的重组大肠杆菌BL21 (DE3)工程菌 ${ }^{[10]}$, 该菌株表达的重 组环氧化物水解酶具有高立体选择性, 能有效催化ECH 的不对称水解合成(R)-ECH. 但由于环氧化物对生物催 化剂有毒害作用, 且化学性质活泼, 在单一水相中易发 生自发水解反应, 导致反应效率不高 ${ }^{[11]}$, 而应用有机溶

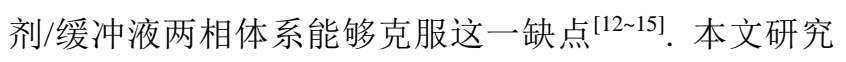
了以重组大肠杆菌BL21 (DE3)全细胞为生物催化剂, 在 有机溶剂/缓冲液两相体系中催化拆分 $\mathrm{ECH}$ 不对称水解 反应制备 $(R)-\mathrm{ECH}$, 系统探讨了两相体系对反应的影响
规律.

\section{2. 实验部分}

\section{1. 全细胞的培养及制备}

重组大肠杆菌E. coli BL21 (DE3)菌株由本实验室 保存 ${ }^{[10]}$, 培养方法见文献[16]. 获得的菌体用生理盐水 悬浮洗涤后, 于 $10000 \mathrm{r} / \mathrm{min}$ 离心 $10 \mathrm{~min}$ 收集菌体, 于 $-20^{\circ} \mathrm{C}$ 储存.

\section{2. 两相体系中生物催化拆分ECH反应}

ECH, (S)-ECH和(R)-ECH (99\%)标准品为西安福晨 化学有限公司产品. 其他材料均为市售色谱纯或分析纯 试剂.

在50 ml带塞转化瓶中, 加入适量湿菌体和一定体积 的磷酸盐缓冲液 $(0.2 \mathrm{~mol} / \mathrm{L}, \mathrm{pH}$ 8.0)与异辛烷, 在适当条 件下磁力搅拌 $(400 \mathrm{r} / \mathrm{min}) 15 \mathrm{~min}$, 加入适量外消旋 $\mathrm{ECH}$, 继续摚拌. 定时取样, 离心 $(12000 \mathrm{r} / \mathrm{min} \times 2 \mathrm{~min})$ 加入 800 $\mu \mathrm{l}$ 乙酸乙酯萃取 $\mathrm{ECH}$, 取 $200 \mu \mathrm{l}$ 加入含 $800 \mu \mathrm{l}$ 乙酸乙酯的 $\mathrm{EP}$ 管中进行稀释, 加入适量无水硫酸钠干燥, 供气相色 谱分析.

气相色谱分析采用日本岛津GC-14A型气相色谱 仪, 手性色谱柱 BGB-175 (30 m × $0.25 \mathrm{~mm} \times 0.25 \mu \mathrm{m})$, 氢离子火焰检测器. 检测条件: 进样器温度 $220^{\circ} \mathrm{C}$, 检测 器温度 $220^{\circ} \mathrm{C}$, 柱温 $90^{\circ} \mathrm{C}$, 保留 $7 \mathrm{~min}$, 载气为 $\mathrm{He}(1.6$ $\mathrm{ml} / \mathrm{min}$ ), 分流比 1:40. (R)-ECH和(S)-ECH的保留时间分 别为 5.3 和 $5.6 \mathrm{~min}$.

根据剩余ECH计算摩尔产率 $(Y)$ 和时空产率 $\left(Y_{1}\right)$, 产 物的光学纯度由 ee值表征, 计算式如下: $Y=c / c_{0} \times$ $100 \%$, 式中 $c_{0}$ 和 $c$ 分别为反应起始和反应结束时 $\mathrm{ECH}$ 的 摩尔浓度; $Y_{1}=c / t$, 式中 $c$ 和 $t$ 分别为 $(R)-\mathrm{ECH}$ 的摩尔浓度 和反应结束的时间; ee $=\left(c_{R}-c_{S}\right) /\left(c_{R}+c_{S}\right) \times 100 \%$, 式中 $c_{R}$ 和 $c_{\mathrm{S}}$ 分别为 $(R)-\mathrm{ECH}$ 和 $(S)-\mathrm{ECH}$ 的摩尔浓度.

\section{3. 结果与讨论}

\section{1. 有机溶剂的选择}

一般而言, 有机溶剂对生物细胞(酶)有一定的毒害 作用, 导致生物细胞(酶)的活性下降. 本文选用6种不同 
疏水性的有机溶剂(异丁醇、异丙醇、环己烷、异辛烷、 正庚烷、正己烷)作为两相反应体系的有机相, 考察了不 同有机溶剂对环氧氯丙烷溶解能力和对重组大肠杆菌 BL21全细胞催化外消旋环氧氯丙烷不对称水解反应的 影响.

对底物高的溶解能力是篮选有机溶剂时需考虑的 一个重要因素 ${ }^{[17]}$. 实验测定了6种有机溶剂对环氧氯丙 烷在的溶解能力. 结果表明, $\mathrm{ECH}$ 在异辛烷、正庚烷和正 己烷中的溶解度 $\left(20^{\circ} \mathrm{C}\right)$ 分别达到 $22.1,18.5$ 和 $19.0 \mathrm{~g} / 100$ g溶剂, 与异丁醇、异丙醇和环己烷互溶. 水相中ECH溶 解度(6.58)较低, 而有机溶剂则对ECH均具有较高的溶 解能力. 除了对底物的溶解性, 有机溶剂的生物相容性 是有机相篮选择时需考虑的另一个重要因素. 如图1所 示, 当异辛烷作为有机相时, 产物的摩尔产率和ee值较 高. 这可能是因为异辛烷生物相容性好. 尽管环己烷和 正庚烷有较高的ee值, 但是产物的摩尔产率低. 另外, 以 异丁烷和异丙醇为溶剂时, ECH的ee值几乎为零, 使用 正己烷时, ECH的ee值和产物摩尔产率均较低. 这可能 是因为这些溶剂对重组E.coli BL21 (DE3)表达的环氧化 物水解酶的毒害作用较大, 影响了其催化活性. Bottalla 等 ${ }^{[18]}$ 和Gong等 ${ }^{[11]}$ 也发现, 异辛烷对巨大芽狍杆菌和黑 曲霉环氧化物水解酶具有良好的生物相容性. 因此, 本 文选择异辛烷作为两相体系中的有机溶剂.

\section{2. 两相体积比的影响}

两相系统中有机溶剂与水相的体积比 $V_{\mathrm{o}} / V_{\mathrm{a}}$ 影响反 应的原因被认为是, $V_{\mathrm{o}} / V_{\mathrm{a}}$ 的变化会改变两相界面积, 从 而影响生物催化的速率 ${ }^{[19]}$. 实验以初始反应速率为目 标, 考察了 $V_{\mathrm{o}} / V_{\mathrm{a}}$ 对反应的影响, 结果见图 2. 可以看出, 随着异辛烷含量的增加, 初始反应速率逐渐增大, 但当 异辛烷体积比增大到 $70 \%$ 后, 初始反应速率迅速下降. 一般来说, 由于有机溶剂普遍具有一定毒性, 酶或活细 胞一旦与之接触, 总会出现一些变性和失活的现象. 在 有机相/水体系中, 底物ECH大部分存在于有机相中, 其 在水相中的浓度较低, 减少了底物对菌体细胞的毒害与 抑制作用. 另一方面, 随着 $V_{\mathrm{o}} / V_{\mathrm{a}}$ 比逐渐增大, 过量的有 机溶剂会夺取酶表面的水膜, 使酶活力降低甚至失去活 性 ${ }^{[20]}$. 因此, 根据初始反应速率的变化情况, 最适 $V_{\mathrm{o}} / V_{\mathrm{a}}$ 为 $7: 3$.

$\mathrm{ECH}$ 和副产物3-氯-1,2-丙二醇( $\mathrm{MCH})$ 在异辛烷/缓 冲液双相体系中的分配系数见表1. 可以看出, 在所考察 的 $V_{\mathrm{o}} / V_{\mathrm{a}}$ 值范围内, 环氧氯丙烷在两相中的分配系数随着 异辛烷含量的增加而迅速提高, 而副产物 $\mathrm{MCH}$ 的分配系
数均趋于零. 这说明有机溶剂不仅提供了两相界面, 而 且可以作为萃取产物的溶剂, 及时有效地将产物 $(R)-\mathrm{ECH}$ 从水相中萃取出来, 而副产物 $\mathrm{MCH}$ 则主要分配 在水相中. 因此, 采用异辛烷/缓冲液两相体系可简化产 物 $(R)-\mathrm{ECH}$ 的分离纯化过程.

\section{3. 反应温度的影响}

在酶促反应中, 温度对催化剂的活性、立体选择性 和稳定性以及反应平衡都会产生影响 ${ }^{[21]}$, 因此本文考察 了 $20 \sim 40^{\circ} \mathrm{C}$ 时全细胞催化环氧氯丙烷的活性变化, 结果 见图3. 当温度由 $20^{\circ} \mathrm{C}$ 逐渐升至 $30^{\circ} \mathrm{C}$ 时, 初始反应速率 和ee值明显增大, 并在 $30^{\circ} \mathrm{C}$ 达到最大值. 当温度超过 30 ${ }^{\circ} \mathrm{C}$ 时, 初始反应速率和ee值开始迅速降低. 温度的升高 使酶的活性中心发生适度的变化, 有利于酶分子与底物 分子的结合, 同时也使两者的碰撞结合几率增加, 因此 使细胞催化反应速率增加. 过高的温度 $\left(30^{\circ} \mathrm{C}\right)$ 导致酶空 间结构的破坏, 菌体活性下降, 导致反应速率和ee值下 降. 这与 Woo等 ${ }^{[9]}$ 和Lee 等 ${ }^{[22]}$ 报道的环氧化物水解酶最 佳反应温度相一致. 因此, 最佳反应温度为 $30^{\circ} \mathrm{C}$.

$\mathrm{ECH}$ 在水相中不稳定, 易发生自发水解反应, 使得 酶催化拆分ECH的产率大大降低 ${ }^{[23]}$. 本文比较了水相 和两相反应体系中ECH的自发水解率, 结果见图4. 可以 看出, $30{ }^{\circ} \mathrm{C}$ 时水相中的水解率为 $7.1 \%$, 而在两相体系中 为 $4.9 \%$, 且随着温度升至 $40^{\circ} \mathrm{C}$, 水相中的水解率达 $10.1 \%$, 而在两相体系中仅为 $7.2 \%$. 由此可见, 两相体系 的应用可以抑制底物的自发水解反应, 从而提高单一手 性产物的产率.

\section{4. 缓冲液 $\mathrm{pH}$ 值的影响}

在两相反应体系中, 催化反应通常发生在被称为催 化剂富余相的水相中, 水相缓冲液的 $\mathrm{pH}$ 值不仅改变了反 应中底物和带有电荷的酶的离子状态, 而且还会影响酶 的催化活性 ${ }^{[24]}$. 本文考察了 $\mathrm{pH}$ 7.0 9.0的缓冲液对全细 胞催化ECH反应速率的影响, 结果见图5. 可以看出, 当 缓冲液 $\mathrm{pH}$ 由 7.0 逐渐升至 8.0 时, 初始反应速率和ee值明 显增加. $\mathrm{pH}$ 超过 8.0 时, 两者开始迅速下降. 这表明 $\mathrm{pH}=$ 8.0 时细胞具有最大的催化活力. 这与多数文献结果相 符 ${ }^{[8,25,26]}$. 因此, 全细胞催化反应的最适 $\mathrm{pH}$ 可确定为8.0.

\section{5. 菌体浓度的影响}

菌体浓度的大小直接与酶量相关, 因而菌体浓度直 接影响催化效率: 菌体浓度越高, 催化相同浓度底物的 催化反应速率就越大, 但菌体过量又会影响传质作 用 ${ }^{[27]}$. 因此, 本文在保持底物浓度固定的条件下考察了 菌体浓度对反应的影响, 结果见图6. 可以看出, 当菌体 
浓度小于 $0.07 \mathrm{~g} / \mathrm{ml}$ 时, 随着细胞用量的增加, ee值、反应 产率和初始反应速率明显增大；当菌体浓度高于 0.07 $\mathrm{g} / \mathrm{ml}$ 时, 初始反应速率开始减少, 而ee值和反应产率基本 保持不变, 说明此时催化剂已经过量. 因此, 为了拆分反 应能够经济有效的进行, 确定细胞浓度为 $0.07 \mathrm{~g} / \mathrm{ml}$.

\section{6. 底物浓度的影响}

高底物浓度一般会对细胞或酶产生毒害作用, 影响 其活性, 但底物浓度过低则影响反应效率 ${ }^{[28]}$. 本文在异 辛烷/缓冲液两相体系中, 以ee值为目标, 考察了底物浓 度对反应的影响, 结果如图7所示. 可以看出, 当底物 $\mathrm{ECH}$ 浓度从 382.7 逐渐升至 $574 \mathrm{mmol} / \mathrm{L}$ 时, 菌体均能将 $\mathrm{ECH}$ 拆分完全, $(R)-\mathrm{ECH}$ 的ee值均可达 $99 \%$ 以上; 当浓度 高于 $574 \mathrm{mmol} / \mathrm{L}$ 时, $(R)-\mathrm{ECH}$ 的ee值明显降低, 当底物浓 度为 637.8 和 $765.4 \mathrm{mmol} / \mathrm{L}$ 时, $(R)-\mathrm{ECH}$ 的 ee值分别仅为 $46.2 \%$ 和 $18.9 \%$. 这主要是由于底物 ECH是非天然化合 物, 其生物相容性较差, 高浓度ECH会对细胞产生毒害 作用, 影响环氧化物水解酶全细胞催化的活性和立体选 择性. 因此, 为了使此拆分反应能够有效进行, 确定最优 $\mathrm{ECH}$ 浓度为 $574 \mathrm{mmol} / \mathrm{L}$.

\section{7. 机械摚拌反应器中催化拆分 ECH的反应进程曲线}

按上述优化条件, 在 $2 \mathrm{~L}$ 机械搅拌反应器中加入 $1 \mathrm{~L}$ 反应液(异辛烷/ $\mathrm{pH} 8.0$ 磷酸盐缓冲液体积比 $7: 3$ ) 、 0.07 $\mathrm{g} / \mathrm{ml}$ 菌体和 $574 \mathrm{mmol} / \mathrm{L}(R, S)-\mathrm{ECH}$, 反应温度 $30^{\circ} \mathrm{C}$, 摚 拌, 连续取样并分析检测. 如图8所示, 菌体对 $\mathrm{ECH}$ 表现 出良好的立体选择性, 对(S)-ECH的转化速率明显快于 $(R)-\mathrm{ECH}$, 水解产物为 $\mathrm{MCH}$. $45 \mathrm{~min}$ 后终止反应, 此时 $(R)-\mathrm{ECH}$ 的浓度达到 $215 \mathrm{mmol} / \mathrm{L}$, 摩尔产率为 $37.5 \%$, ee 值为 $99.3 \%$, 时空产率达到 $0.286 \mathrm{~mol} /(\mathrm{L} \cdot \mathrm{h})$. 与单一水相 体系相比, 异辛烷/缓冲液两相反应体中底物ECH浓度由
369.9增至574 mmol/L, 提高了 55.2\%, (R)-ECH时空产率 由 0.144 增至 $0.286 \mathrm{~mol} /(\mathrm{L} \cdot \mathrm{h})$, 提高了 $98.6 \%$.

表2归纳了相关文献中生物法拆分 $\mathrm{ECH}$ 的反应结果. 由表可见, 已报道的生物拆分反应均在单一水相或有机 相中进行, 底物浓度和产率普遍不高. Woo等 ${ }^{[9]}$ 在单一 水相体系中利用Novosphingobium aromaticivorans重组 环氧化物水解酶催化拆分 ECH, 底物 ECH浓度较高, 达 $500 \mathrm{mmol} / \mathrm{L}$, 但 $(S)-\mathrm{ECH}$ 产率仅为 $10.7 \%$. Lee等 ${ }^{[22]}$ 在单 一有机相中利用Rhodotorula glutinis环氧化水解酶拆分 $\mathrm{ECH}$, 尽管 $(R)-\mathrm{ECH}$ 产率可达 $28.5 \%$, 但其底物浓度仅为 $20 \mathrm{mmol} / \mathrm{L}$. 可见, 本文采用的两相全细胞催化体系中底 物浓度和手性环氧氯丙烷产率均较高.

\section{4. 结论}

系统研究了有机溶剂/缓冲液两相体系中重组大肠 杆菌E.coli B21全细胞催化环氧氯丙烷(ECH)不对称水 解反应, 考察了各相关因素对该反应的影响. 在异辛烷/ 缓冲液两相反应体系中, 全细胞酶能高效率、高立体选 择性地催化水解(S)-ECH, 得到 $(R)-\mathrm{ECH}$. 异辛烷对底物 的溶解能力较强, 生物相容性较好, 故可有效提高反应 体系中的底物浓度, 并抑制底物的非酶水解, 从而提高 了底物浓度和时空产率. 在最优反应条件下, 该反应的 底物浓度、摩尔产率、时空产率和产物的ee值分别为574 $\mathrm{mmol} / \mathrm{L}, 37.5 \%, 0.286 \mathrm{~mol} /(\mathrm{L} \cdot \mathrm{h})$ 和 $99.3 \%$. 与已有文献报 道相比, 本方法有效提高了底物浓度和产率. 然而, 由于 有机溶剂通常对生物催化剂有一定的毒害作用, 且大量 有机溶剂的使用易造成环境污染. 因此, 本课题组正致 力于有机溶剂的回收再利用以及连续化两相反应的研 究, 以期提高溶剂使用效率, 减少有机溶剂用量. 